\title{
Práxis enunciativa no telejornal: tensividade em notícia
}

Maria Lúcia Vissotto Paiva DINIZ (Universidade Estadual Paulista)

RESUMO: A práxis enunciativa, conceito explorado pela semiótica tensiva, pode contribuir para a análise do telejornal por apresentar os meios de abordar o sentido, não apenas como representação, mas como espaço-tempo mais ou menos tenso e extenso de uma presença. A análise de uma reportagem elucidará sua construção e a pertinência do método.

PALAVRAS-CHAVE: Comunicação; Telejornal; Semiótica Tensiva; Práxis Enunciativa; Presença

RÉSUMÉ: La praxis énonciative, concept exploré par la sémiotique tensive, peut contribuer à l'analyse du journal télévisé en présentant les moyens d'aborder le sens, non seulement comme une représentation, mais comme un espace-temps plus ou moins intensif et extensif d'une présence. La vidéo d'un reportage sera analysée avec l'objectif de rendre également claires la théorie et la construction du texte.

MOTS-CLÉS: Communication; Journal Télévisé; Sémiotique Tensive; Praxis Enonciative; Présence. 


\section{Introdução}

Propomos a hipótese de que, se de um lado as estruturas profundas da significação contêm em sua raiz, segundo Greimas, uma polemização do sentido que a narratividade proppiana realiza, por sua vez, as "espécies de relação" de Bløndal indicam uma patemização do sentido, que os afetos do sujeito transformam em discurso." Claude Zilberberg (2001: 113-114)

A informação televisiva é um relato sintético e sincrético, uma construção que envolve vários atores, técnicas e linguagens diferentes. Esse afluxo de linguagens, cada uma com seu plano de expressão que pressupõe um plano de conteúdo, converge para efeitos de sentido espetaculares. A imagem em movimento (kínesis) e os recursos da cinética produzem o efeito de realidade, mimesis do mundo natural, que conferem ao produto final veracidade, impacto e autenticidade. Realizado de forma coletiva, o texto final audiovisual decorre de uma enunciação que não pode ser desmembrada. Toda enunciação pressupõe a competência do enunciador diante de dois fatores: as linguagens como sistema virtual e o mundo natural, sistema realizado. A enunciação é uma práxis na medida em que dá certo estatuto de realidade aos produtos de linguagem. Ela reincorpora em linguagem o mundo natural. Sem isso, os discursos não teriam nenhuma eficácia. Responsável pelas operações inerentes ao ato de discurso, convoca grandezas heterogêneas e oscilações tensivas presentes tanto na produção quanto na interpretação do discurso, seja ele verbal ou não-verbal (Fontanille e Zilberberg, 2001: 172).

Em abordagens anteriores (Diniz, 2004), tentamos dessincretizar o texto do telejornal (TJ), identificando as diferentes linguagens que o compõem e apontando as relações que estabelecem entre si, ora reforçando ora introduzindo novos efeitos. Evidenciamos as diferentes equipes que contribuem para sua produção e demonstramos como o telejornal traz a informação em forma de um espetáculo ao vivo e em cores, como se o acontecimento fosse sua própria transmissão e o telespectador, uma testemunha ocular (Idem, 2005). Tratamos desse envolvimento sob a forma de contratos decorrentes das dimensões: cognitiva, pragmática, estésica e passional, sob a égide do contrato fiduciário do crer. Apontamos o envolvimento afetivo do enunciatário, receptáculo de impulsos que desencadeiam sensações, emoções, sentimentos e paixões que, acoplados ao acontecimento, permitiram analisar matérias de TJs, enfocando tanto a produção quanto a interpretação da relação enunciador/enunciatário, como promotora de efeitos de sentido que garantem a comunicação efetiva e afetiva.

A investigação da carga afetiva do TJ levou-nos em direção à semiótica tensiva, terreno árido, de difícil compreensão, mas começa a fazer sentido depois da leitura do artigo Del afecto al valor de Claude Zilberberg (2001). Percebemos que, antes de firmar os contratos, há um campo de abordagem que oferece uma multiplicidade de operações que são assumidas pelo enunciador. Ali estão os recursos do texto antes de sua colocação em discurso. Dali emerge a significação conduzida pela afetividade, a qual recebemos sob a ação da intensidade (Zilberberg, 2002a: 01; 2002b: 113). A tensividade é um lugar imaginário de operações onde atuam duas dimensões: intensidade e extensidade, na primeira, estão os estados de alma (o sensível), na segunda, os estados de coisas (o inteligível). É a intensidade que rege a extensidade 
(Ibidem: 03; 115). Investigar esse momento é restituir o sentido dessa experiência humana que consiste em produzir e interpretar algo significante. E no telejornal, a intensidade é fator preponderante. Diríamos mesmo que ali, formas tensivas de diferentes linguagens se unem para produzir a hiperemoção, aspecto esboçado em artigo anterior (Diniz, 2006), cuja análise será retomada e aprofundada com elementos da teoria.

\section{Do método}

A idéia é um edifício-acontecimento. Paul Valéry A semiótica privilegiou o "edifício" em detrimento do "acontecimento", o "sistema" em vez do "ritmo". Claude Zilberberg (2001: 114)

O instrumental que a Semiótica criou, o percurso gerativo, é uma representação das etapas de construção do sentido que sintetiza nossa prática espontânea de buscar a significação nos textos. Indica uma trajetória de sucessivas abstrações, que conduzem o analista como um fio de Ariane no labirinto do texto. Entretanto, como todo instrumental analítico, é um modelo arbitrário, útil, porém não definitivo. Nunca de forma abrupta, mas progressiva, a pesquisa semiótica foi investigando certos elementos e incorporando novas noções. A modalização no nível narrativo, por exemplo, representada pelo querer, dever, saber e poder-fazer, a princípio, apenas observada nos actantes do enunciado, passou da ação à paixão, ao abordar o nível do "ser" tratado em Semiótica das paixões (Greimas e Fontanille, 1993). Do mesmo modo, a axiologia do discurso, os valores eufóricos/disfóricos, também mereceu um aprofundamento, determinando um viés que conduz aos aspectos tensivos como parâmetro para a análise do universo sensível.

Essa nova formulação teórica que foi inserida no edifício semiótico não invalida a forma de descrição do percurso gerativo, nem os modos de conversão de um nível a outro. Ao contrário, atribui ainda mais consistência ao modelo, sugerindo soluções a questões pendentes ao revelar que, em cada passagem de um nível a outro, existe um espaço, o espaço tensivo. Assim, a semiótica tensiva é um modelo que analisa as gradações do sentido, uma forma de medir a tensão do discurso, que pressupõe a ambivalência do objeto e a instabilidade do sujeito. Trata o sentido não apenas como representação, mas no espaço-tempo mais ou menos tenso e extenso de uma presença, que é um pré-sentido, ou seja, a relação ambivalente entre sujeito e mundo natural. Essas relações representam o motor de toda ação, que consiste na focalização (visée) e na apreensão (saisie), operações que revelam o desejo de expressar o valor de um campo de presença num campo de significação. Essas sutilezas do devir do sujeito são assumidas pela práxis enunciativa, terreno híbrido, entre teoria e estética ${ }^{1}$.

No campo da tensividade operam as modulações tensivas (ligadas à percepção) e instabilidades passionais e fóricas (ligadas aos sentimentos), apreensões anteriores que se converterão, posteriormente, em semas, modalidades, temas e figuras do percurso gerativo. Os teóricos da tensividade preferem conceber esse momento anterior como o da práxis enunciativa, que parte de valências para escolher os valores que imprimirá em todos os níveis de seu discurso. Assim, os valores de ordem tensiva atuam na ordem 
actancial, modal, aspectual, temporal e espacial, ponto de partida para descrições que pretendem revelar a forma semiótica, imanente ao texto, construídas por operações conceituais que atuam no momento de sua enunciação.

Portanto, essa operação trabalha com as noções de tempo e espaço num nível mais profundo: um tempo-espaço que pressupõe a noção de foria e tensão, ou seja, estamos na última instância de abstração do percurso gerativo (aquém do nível fundamental). Decorrente da presença sensível do homem (enunciador universal), a foria determina o valor tensivo "primitivo", recoberto pela oposição contenção/distensão manifestada na descontinuidade/continuidade do discurso, que se traduz, de um lado, por parada (no tempo) ou fechamento (espaço), de outro por parada da parada (continuidade) ou abertura (ampliação do espaço), categorias assim denominadas por Zilberberg em seu livro Essai sur les modalités tensives (1981).

Há duas dimensões tensivas: na verticalidade estão os valores de intensidade, que correspondem à temporalidade suspensa, remissiva, um ponto tenso, de espera, de suspensão, a parada, e, na horizontalidade, estão os valores de extensidade, que pertencem à temporalidade corrente, ao tempo que passa inexoravelmente, se distende, se difunde. Do mesmo modo, o espaço se reduz, se fecha quando ocorrem os valores de intensidade e o espaço se abre, distende quando ocorrem valores de extensidade.

Os termos intensos sobre a cadeia extensa produzem uma alternância dinâmica que pode ser expressa pela atuação da parada sobre a continuação e sobre a própria parada originando a continuação da parada e parada da parada (Zilberberg, 1988: 101) Dessa forma, o nível tensivo converte-se em nível aspectual (transforma as ações em processos) ${ }^{2}$, que analisa o devir "ascendente ou descendente de uma intensidade" capaz de fornecer ao observador atento "algo mais ou algo menos" (Zilberberg, 2002a: 02; 2002b: 115).

\section{Para definir práxis enunciativa}

A semiótica standard demorou para acolher a foria e a estesia em seu quadro conceitual, hoje consideradas como categorias de primeira grandeza, pois são condutoras da afetividade que atua na dimensão da intensidade. $\mathrm{Na}$ produção do discurso, o primeiro passo está na "tomada de posição" do enunciador (Fontanille, 1998: 271), que delimita o campo discursivo desse discurso específico que ele produz. De um lado, o enunciador se posiciona no espaço e no tempo da enunciação: um "eu", aqui, agora, que se opõe a um "ele", lá, então, domínio do enunciado; de outro, uma delimitação do campo: extensão maior ou menor correlacionada à intensidade também maior ou menor, relativa à aproximação ou afastamento do centro enunciador. A correlação dos eixos intensidade/extensidade, noção que será aprofundada ao longo dessa análise, decorre de estratégias próprias da práxis enunciativa que corresponde às operações realizadas pelo enunciador (enunciatário sempre pressuposto) na própria instância da enunciação, momento imediatamente anterior à colocação em discurso. A práxis, ao aproximar o discurso do centro enunciativo, imprime maior ênfase nos conteúdos, atuando no eixo da intensidade, ao passo que, ao afastar-se do centro, provoca um alargamento do campo, uma dilatação no eixo da extensidade. Em outras palavras, o que está próximo tem efeito maior, toca-nos muito mais do que o que está distante e que mal percebemos. 
Essa "elasticidade do discurso", já apontada por Greimas como uma possibilidade das línguas naturais (Greimas e Courtés, 1983: 138) permitiu aos teóricos mais recentes, num primeiro momento, apontar dois movimentos da práxis enunciativa manifestável por qualquer substância da expressão: a condensação e a expansão ${ }^{3}$. A primeira operação consiste em contrair o discurso, evidenciando sobretudo os aspectos mais marcantes, enquanto na expansão o discurso distende-se em digressões e exemplificações. Essa elasticidade do discurso permitiu que o conceito de profundidade, que Claude Zilberberg vem construindo há longo tempo, detalhado e aprofundado posteriormente (Fontanille e Zilberberg, 2001: 18), instaurasse no contínuo as noções de proximidade/distância que possibilitaram depreender as correlações intensidade/ extensidade, enquanto nível "pré-fundamental", onde estão as pré-condições tensivas de toda e qualquer geração de sentido.

Acreditamos que essas noções, que embasam a semiótica tensiva, edifício que vem sendo construído por Claude Zilberberg, seu precursor, representam uma abordagem pertinente para tratarmos de textos telejornalísticos, pois cada reportagem que nos é apresentada é uma condensação, com efeitos de aproximação que pretendem mimetizar o fato, um relato que insiste na simultaneidade e na sucessão, criando relações intensas, mas também extensas, necessárias a nossa práxis existencial. $\mathrm{Na}$ verdade, a práxis enunciativa será investigada apenas em uma de suas operações, aquela que incide na contenção e elasticidade do discurso.

\section{A TV e a práxis enunciativa}

Em meio ao fluxo contínuo da programação das tevês, o telejornal chega como uma promessa de informação. Cada notícia rompe a continuidade, instaura o descontínuo, desencadeando a curiosidade (uma paixão primária), toca-nos pelo emocional (afeto) e provoca a adesão contratual na dimensão cognitiva e pragmática (fiduciária). Cada matéria surge no vídeo como um espetáculo pelos recursos audiovisuais de que a televisão dispõe. Seu formato de narrativa-descritiva ressalta com intensidade tudo o que pode, sob a égide do afeto (foria e estesia). Se for a notícia de fato inesperado, o TJ tentará recriá-lo, com inserção de testemunhas (sonoras) e outros efeitos de referencialização, imagens de arquivo, fotos, reconstituição dos fatos etc; se for notícia de fato esperado, pode assumir ainda maior magnitude, pois toda a parafernália de gravação ocupa um lugar reservado in loco, com direito a enviado especial, depoimentos, tomadas gerais ou em zoom efeitos de desenhos de computação gráfica etc. O TJ é sempre um espetáculo intenso, usa e abusa da intensidade, mas sabe dosar a extensidade.

Destacamos para este estudo o vídeo da matéria "Um dia que ficará na história", do Jornal Nacional (JN), notícia de fato esperado: o funeral do Papa João Paulo II, apresentado na noite de 08/04/2005, que será analisado sob o enfoque da semiótica tensiva. Utilizaremos o relato da matéria, transcrito no Anexo 1, e algumas imagens captadas em forma de foto, Anexo 2.

A edição do vídeo, acompanhado da narração da repórter, resume em cinco minutos e dezesseis segundos a cerimônia que transcorreu no espaço de quase três horas. A maior parte dos aspectos assinalados no texto estavam gravados no videotape da cerimônia, outros decorrem de "interpretações" da repórter e do enunciador 
complexo, uma equipe de profissionais, cuja intencionalidade pressupõe um fazer jornalístico pautado pela própria empresa, pelo gênero a que pertence, pelo estilo do profissional. Entretanto, o enunciador é também um sujeito inserido num tempo vivido (sua própria emoção e presença existencial) e, dentre outras interferências, deixa-se "contaminar" por outros discursos, pelo contexto, por valores sociais, religiosos, enfim, pela cultura.

A análise do texto pode ser esclarecedora, se nos for permitido considerar, de um lado, a gravação em vídeo da cerimônia integral (duração de 3 horas) como o mundo vivido, e de outro lado, a edição (5 minutos e 16 segundos) como o discurso em ato. Esse desdobramento pode ser extremamente didático para destacarmos como atua a práxis enunciativa nesse nível "pré-fundamental" da tensividade; como ela recolhe da gravação completa do vídeo os elementos que julga pertinentes para a construção do texto final. Imagem e relato (texto oralizado) se acoplam e se fundem, organizam o conteúdo, apontam "interpretações" que trabalham o eixo da intensidade para dar mais brilho ao discurso, direcionar a foria e provocar a estesia. É preciso romper com a extensidade, eixo predominante, uma decorrência inevitável de nossa existência, essa continuidade natural, para a qual tudo corrobora ${ }^{4}$. Por isso, a práxis enunciativa do texto em análise recorreu a elementos que construíram o vazio de uma perda (morte do papa), a emoção de um momento (última homenagem), selecionando apenas as imagens que poderiam construir o sentido pretendido 5 . De qualquer forma, o próprio decorrer da matéria, da missa e do enterro, retoma a continuidade, a dimensão da extensidade.

Outro aspecto a considerar é o tempo. Se a práxis está no devir de uma enunciação, como ignorar a rapidez ou a lentidão, o andamento do tempo? Segundo Zilberberg, "o andamento é mestre tanto do nosso pensamento quanto de nossos afetos pois, como um déspota, ele controla os aumentos e as diminuições que constituem nossa vivência" (2002a: 02; 2002b: 114 ).

Ao apontar essas ações que estão por trás do texto, acreditamos que a semiótica tensiva pode oferecer um aparato pertinente para a investigação do sentido anterior à oposição primordial registrada no quadrado semiótico, o espaço do pré-sentido, onde predominam valências como se fossem saliências semânticas, que a práxis enunciativa converte em valores por processos que pretendemos evidenciar na análise.

\section{A análise}

Inicialmente, todos concordam que (o discurso) coloca em relação pelo menos duas grandezas: pelo menos dois conjuntos semânticos, duas posições argumentativas, dois graus de intensidade ou extensidade, dois graus de elaboração conceitual ou de assunção enunciativa. Em seguida, nos esforçamos em caracterizar a relação entre essas duas grandezas, que pode ser de conflito semântico ou enunciativo, de deslocamento actancial ou hierárquico, de diminuição ou de aumento sobre um gradiente. E finalmente, procuramos caracterizar o resultado, o efeito pragmático ou a conseqüência interpretativa. Boudron e Fontanille (2000: 07)

A primeira preocupação do TJ é inserir o telespectador no tempo e no espaço do discurso, com a preocupação de criar efeitos de sentido de presentificação. Assim, a práxis enunciativa se instaura pela tomada de posição de sucessivos enunciadores: a 
apresentadora Fátima Bernardes, no estúdio do Rio de Janeiro (Fig. 1), chama "ao vivo William Bonner, diretamente de Roma". Este surge no vídeo, tendo ao fundo a silhueta da Catedral de São Pedro iluminada (Fig. 2), e anuncia a reportagem, atribuindo-lhe valores históricos. Essa estratégia, denominada por Barthes de "mise en abîme" é uma técnica de referencialização no tempo da notícia, dando-lhe maior impacto. O termo "ao vivo" confere intensidade, inverídica no caso, pois o funeral foi realizado pela manhã e, com o fuso horário, quando o JN entra no ar no Brasil, já passa da meia-noite em Roma. Mas fica o efeito de presentificação garantido. Do mesmo modo, na reportagem, narrada em tom dramático (prosódia) por Ilze Scamparini, a repórter surgirá no vídeo três vezes (Fig. 7, 9 e 11, correspondente aos parágrafos 3, 6 e 10 do texto transcrito) insistindo no efeito de aproximação do texto ao centro enunciativo. Para a inserção do telespectador no espaço, a reportagem inicia com uma tomada geral da Basílica (Fig. 3) seguida de uma tomada geral da Praça (Fig. 4), cada uma de ângulos opostos: imagens gravadas de pontos elevados. Em seguida, a câmera, num movimento da esquerda para a direita, focaliza a fachada do Vaticano e a escadaria onde será celebrada a cerimônia (Fig. 5 e 6).

"Um dia que ficará na história" (Anexo 1) é uma metáfora, um instante de plenitude estética e estésica surpreendido na continuidade amorfa do cotidiano. Lembra a "fratura", "essa inesperada suspensão do tempo" de que nos fala Greimas (2002: 23). Apresenta uma situação terminativa: a morte do papa e uma situação incoativa: a possibilidade de sua santificação. $\mathrm{O}$ fato compreende, ao mesmo tempo, o funeral (última homenagem e enterro), de valor terminativo, e a missa de corpo presente (um ritual) de valor incoativo e durativo, cuja função é abreviar e concentrar o tempo para aliviar a multidão de fiéis (e os telespectadores) da dor causada pela perda do valor.

A partir da oposição /humano/vs /divino/, isotopias presentes em nossa cultura, há uma série de possibilidades que pode ser adotada pela práxis enunciativa: ilustrar só uma isotopia, a da terminalidade ou da incoatividade, ou trabalhar ambas, enfatizando ora uma ora outra. É o que acontece em nosso texto: no início, predomina a isotopia /humano/, porém, a isotopia /divino/ vai sendo construída aos poucos e predomina no final. Ao conservar as duas isotopias em tensão, ambas são atualizadas, sendo uma realizada, outra potencializada. Assim, o enunciado é percebido como concentrado, com picos de intensidade, e difuso, pois a extensidade decorre naturalmente do próprio ritual e do desenvolvimento do relato. A práxis enunciativa inscreve-se no âmbito de uma dimensão tensiva: o atualizado é o conteúdo manifesto e o potencializado é o conteúdo latente. Sua alternância supõe que a isotopia figurante /humano/ vai e vem entre atualização e realização e a isotopia figurada /divino/ oscila entre potencialização e realização, ou seja, isotopias em flutuação (Fontanille e Zilberberg, 2001: 187).

Tanto no relato quanto no texto visual, o conteúdo intenso (eixo da intensidade) rompe a continuidade, introduzindo o sentimento de falta, de "imperfeição" 6 . Esse desequilíbrio entre tempo e espaço, lembra a parada (Zilberberg, 1988: 113), uma suspensão do tempo que introduz a espera e a ansiedade, marcadas no texto em quatro formas de expressão: 1. pela negação: "Não é uma manhã de Cracóvia"; 2. pelo emprego da conjunção adversativa "mas da Roma que ele adotou". Assim, já no primeiro período, Roma é o espaço do /desterro/ e da /abnegação/, decorrentes de um dever-fazer imperativo para o papa: a distância de sua terra natal e a 
adoção por Roma. Nessa atmosfera predominantemente disfórica, as imagens da multidão de fiéis na Praça de São Pedro são acompanhada do texto oralizado que introduz o item 3. a despedida final, uma ruptura inevitável: "são 300 mil que esperam ver pela última vez...", que pressupõe um querer continuar a ver desse sujeito coletivo, mas um não-poder abrupto (do sobrevir) ; 4. a ruptura maior: "um papa na sua dimensão humana", "um corpo" (Par. 1), "o caixão" (Par. 2), o sujeito reduzido a um ser /humano/ pressupõe uma visão materialista introduzida num campo cultural religioso.

Entretanto, há um anseio de extensidade latente, em que o próprio funeral (ou a missa de corpo presente) tem seu valor de ritual reparador da falta trazendo valores que possam suprir a perda. A práxis enunciativa já elegera uma forma reparadora, algo que pudesse instaurar o equilíbrio, a parada da parada (Ibidem) e a adoção de valores de distensão, de continuidade, do devir de todo sujeito: o restabelecimento do continuum.

A práxis enunciativa adota a oposição virtual, latente desde o início, a santidade do papa para ser inserida gradativamente em figuras que remetem ao /divino/. A frase "O corpo do Papa João Paulo II chega ao sagrado da Basílica de São Pedro" (Par. 3) inicia esse processo que, a partir do parágrafo 4, marca a alternância de expressões das isotopias /humano/ vs /divino/. Os valores de intensidade - a parada insistem no /humano/, evidenciando o papa como um simples mortal: "não tem um rosto", "confinado num caixão" e, novamente, "o corpo do Papa" (Par. 4). Entretanto, a isotopia /divino/ surge no texto, tanto na imagem quanto no relato: "o evangelho aberto" (Par. 4) e "Livro Sagrado" (Par. 5). Em seguida, as imagens mostram o vento sacudindo as saias dos cardeais (Fig. 8) e as páginas do evangelho (Fig. 9). Essas imagens, interpretadas pela repórter no comentário: "O vento que a Igreja acredita ter sido enviado pelo Espírito Santo" (Par. 5), introduzem uma metáfora, figura retórica de grande efeito por evocar a presença divina e proporcionar um momento de estesia.

De forma gradativa e ascendente a santificação do papa é construída no devir do texto, por inclusões tensivas de debreagens, pelas quais outras vozes são convocadas fazendo da enunciação uma ação plural: 1. A voz da multidão: "No meio dos fiéis, faixas já o proclamam santo" (Par. 7) "Santo Subito" (Fig. 10); 2. A voz do cardeal Joseph Ratzinger: "João Paulo II está agora na janela da casa do Pai, nos vê e nos abençoa" (Par. 8) e 3. A voz do próprio papa: "Eu não morrerei completamente" (Par. 14, Fig. 15).

Com o aumento de intensidade do /divino/, a isotopia /humano/ passa a ter um brilho efêmero, desgasta-se pela quantidade de repetição atenuando-se na difusão. No texto, a partir do parágrafo 10, a alternância isotópica apresenta-se do /humano/ em direção ao /divino/: "Acabou o poder temporal de João Paulo II. Fica a força da sua palavra e das lutas que ele travou" (Par. 10); "Na crença dos pontífices romanos, quando um papa morre, passa a ser homem. João Paulo II certa vez confidenciou: 'Eu não morrerei completamente" (Par. 14). Isotopias justapostas, porém, pela ordem seqüencial, indicam uma concessão, o que evidencia mais um recurso retórico ${ }^{7}$.

Os detalhes descritos no relato e as imagens selecionadas pela edição escolhidas no videotape - criam a atmosfera de gravidade da cerimônia (intensidade: tonicidade), mas, pelo próprio discorrer do relato, consolam o telespectador num processo de difusão (extensidade): "A missa de corpo presente é rezada em latim. O coro da Capela Sistina e da Mater Eclaesia aumentam a comoção" (Par. 5), "(um 
funeral) com todas as honras, ritos, trajes e cantos" (Par. 6). O requinte do ritual (visual), a voz do cardeal rezando em latim e as vozes do coro (ambas integradas no áudio) criam uma atmosfera "celestial" e a tripla reiteração "Uma multidão sem precedentes", "Um funeral sem precedentes" (Par.6) e "um papa sem precedentes" (Par.7) são superlativos absolutos que visam à unicidade: hipérboles que levam os fiéis à comoção, catarse necessária para expiar a dor.

Depois que o corpo é conduzido para o interior, a práxis recorre à computação gráfica para produzir desenhos que apresentam, primeiramente, o interior da Basílica, em seguida, a escada central que conduz à Gruta Vaticana e, finalmente, um efeito gráfico de penetração no espaço que acentua a profundidade e a rapidez na sucessão de $\operatorname{arcos}$ (Fig. 12, 13 e 14) que suscita o iminente, o fim último (efeito de intensidade). Esses aspectos contrastam com o lugar sagrado em que o papa será enterrado. Mesmo que o relato insista no /humano/: "O corpo do Papa [...] dois caixões" (Par. 13), "uma simples lápide" (Par. 14), ele potencializa o /divino/: "Túmulo que pertenceu a João XXIII, ao lado de duas rainhas que viraram santas, e perto de Pedro", mais um efeito de concessão que mereceria um aprofundamento.

No final da reportagem, uma foto de arquivo mostra o papa ao lado de uma criança, foto tomada em zoom (Fig. 15), para validar o último período do texto: "quando um papa morre, passa a ser homem. João Paulo II certa vez confidenciou: 'Eu não morrerei completamente'" (Par. 14, grifos nossos). Várias questões poderiam ser assinaladas, das quais salientamos o uso do tempo verbal. Enquanto o texto foi todo construído no presente, temos, no último parágrafo, um pretérito perfeito seguido do futuro do presente: o papa torna-se um sujeito competente que instaura a parada da parada integrando-se no tempo que passa e ocupando seu lugar no espaço, por crer nos valores de abrandamento e de distensão. Sua santificação parece iminente, tema que se expande no tempo e no espaço, atravessa o presente e se projeta no futuro, um tempo ascendente de continuidade perene. A reportagem, que começa com as imagens do pape morto dentro de um caixão, termina com as imagens do papa vivo, imagens de arquivo, para dar o sentido desejado.

\section{Considerações finais}

A práxis enunciativa interessa à semiótica das culturas. Com efeito, ela produz "taxionomias conotativas", ou seja, recortes da macrossemiótica do mundo natural, que são próprios de uma área ou época cultural; essas taxionomias são, por sua vez, constituídas de microssemióticas, lingüísticas ou não-lingüísticas, nas quais cada termo, em razão dos laços de dependência e diferença que o unem aos demais, conota a filiação a um universo cultural particular. Fontanille e Zilberberg (2001: 190-191)

Para o discurso não há uma essência imutável nas coisas. Ele deve estabelecer a grandeza a partir das circunstâncias projetadas no centro do campo de presença, organizar a lista daquelas que são compatíveis naquele momento e a lista das que não o são. Assim há posições proibidas ou permitidas, composições prescritas ou aceitas numa determinada cultura. Ao assumir a isotopia /humano/, no texto analisado, a práxis inseriu valores culturais materialistas, a seguir, estabeleceu a alternância das categorias 
(segundo o modelo ou...ou) para, finalmente transformá-las em coexistência em que duas excluídas aceitam coexistir (segundo o modelo e...e).

Trata-se de um discurso narrativo (evento-estado), que constitui "um esquema no qual são associados os eventos salientes, que são extraídos, em virtude de sua própria intensidade, do repertório pré-narrativo do devir" (Fontanille e Zilberberg, 2001b: 167), cuja tensão (tônica-átona) é de predicação intensiva. Entretanto, a práxis enunciativa introduziu elementos de predicação existencial, pois a ausência é revivificada, convocada como uma presença: 1.histórica: William Bonner afirma que o texto antecipa páginas da história, a vida de Wojtyla é relatada, 2. simbólica e alegórica: o cardinal Ratzinger declara que o papa "está na casa do pai...", e a repórter afirma que o vento é atribuído ao Espírito Santo e apresenta a "confidência" do próprio papa. Estamos diante de um relato mítico, pois a predicação existencial fundamenta o mito, cujas possibilidades decorrem da presença existencial do papa, da Igreja católica como um todo, da cerimônia midiática, da platéia e do telespectador comovidos. A práxis enunciativa recolhe dessa presença múltipla no tempo e no espaço aspectos estéticoestésicos ligados à sensorialidade e à afetividade, capazes de ressemantizar o discurso, dotando-o de uma nova aura semântica, essa aura mítica.

Várias disciplinas investigam a cultura sem tratar da textualidade. A Semiótica tensiva permite analisar a cultura a partir da textualidade. Na práxis enunciativa do TJ, não há apenas uma equipe de profissionais responsáveis por sua produção, mas uma bateria de práticas e de movimentos que são textuais e culturais atuando ao mesmo tempo: microssemióticas nas quais cada termo atua em relacionamentos, dependências e exclusões $^{8}$, indicando sua filiação a um determinado universo cultural. Em qualquer situação, afirma Marrone, (2002: 08), "o TJ busca paixões no mundo para suscitá-las no telespectador, transformando o prosaico material do mundo em um verdadeiro e único espetáculo". E espetáculo único, singular, o "mais", o "maior", instituindo um universo de hipérboles. Eis o modus operandi da práxis enunciativa do TJ.

\section{REFERÊNCIAS BIBLIOGRÁFICAS}

BOUDRON, J.-F; FONTANILLE, J. Sémiotique du discours et tensions rhétoriques. Langages, n. 137 Paris: Larousse, março, 2000.

DINIZ, M.L.V.P. Acontecimento e memória no telejornal: Comunicação efetiva e afetiva. Anais do XXVII Congresso Brasileiro de Ciências da Comunicação, INTERCOM - Porto Alegre, RS. 2004.

http://www.adtevento.com.br/intercom/buscatrabalho.asp? (Acesso em 08/06/2005).

DINIZ, M. L. V. P. O telespectador como testemunha ocular. : Revista Estudos Lingüísticos XXXIV. GEL - Grupo de Estudos Lingüísticos, ISSN: 1413-0939 (p. 10451050), 2005.

DINIZ, M. L. V. P. Telejornal: a hiperemoção em semiótica tensiva. Revista Estudos Lingüísticos XXXV. GEL - Grupo de Estudos Lingüísticos, ISSN: 1413-0939, 2006.

FONTANILLE, J. ; ZILBERBERG, C. Tensão e significação. Trad. Ivã C. Lopes, Luiz Tatit e Waldir Beividas. São Paulo: Discurso Editorial: Humanitas/FFLCH/USP, 2001. 
GREIMAS, A. J. Da imperfeição (original 1987). Trad. Ana Cláudia de Oliveira. São Paulo: Hacker editores, 2002.

GREIMAS, A. J; COURTÉS, J. Dicionário de Semiótica. Trad. Alceu Dias Lima et al. São Paulo: Cultrix, 1983.

GREIMAS, A. J., FONTANILLE, J. Semiótica das paixões: dos estados de coisas aos estados de alma. Trad. Maria José Rodrigues Coracini. São Paulo: Ática, 1993.

HJELMSLEV, L. Prolegômenos a uma teoria da linguagem. Trad. J. Teixeira Coelho Neto. São Paulo: Perspectiva, 2003.

MARRONE, G. Retorica della notizia. Prassi enunciativa nel telejornale. Convegno Narratologia e media, Urbino, Centro de Semiotica 8-10 luglio 2002.

http://www.arcojournal.unipa.it/pdf/marrone_retorica_19_06_03.pdf (Acesso em 31/05/2005).

ZILBERBERG, C. Essai sur les modalités tensives. Amsterdã: Benjamins, 1981. . Raison et poétique du sens. Paris : PUF, 1988.

. "Del afecto al valor" in Fronteras de la semiótica Homenaje a Desiderio Blanco, Universidad de Lima \& Fondo de Cultura Econômica (pp. 109-142), Peru, 2001.

. Précis de grammaire tensive, 2002a

http://www.cludezilberberg.net/htmls/precishtml/Precis.htm Acesso em 11/09/2006.

. Précis de grammaire tensive in Tangence. $\mathrm{N}^{\circ} 70$ (pp. 111-143), 2002b

http://www.erudit.org/revue/tce/2002/v/n70/008488ar.pdf Acesso em 11/09/2006.

\footnotetext{
${ }^{1}$ Poderíamos sugerir que a semiótica tensiva está reunindo os primeiros critérios para uma descrição estética. Aplicada sobretudo em textos literários e artísticos, permitiu a abordagem "estética do telejornal" e "retórica da notícia" preconizada por Gianfranco Marrone (2002).

2 A semiótica tratou da aspectualização apontando os semas aspectuais de incoatividade, duratividade e terminatividade (Greimas e Courtés, 1983: 30).

${ }^{3} \mathrm{O}$ "aumento" ou a "diminuição" da intensidade produz sentido, pois o acento ocupa um lugar tão importante que não é possível acreditar que ele não tenha nenhum papel no plano do conteúdo (Zilberberg, 2002a: 02; 2002b: 113).

${ }^{4}$ Zilberberg afirma que "a estesia se dirige infalivelmente para a anestesia" (2002a: 02; 2002b: 113), o que indica que a extensidade é o sentido obrigatório, normal, natural de tudo.

5 A missa de corpo presente estendeu-se por quase 3 horas, o que implica momentos de monotonia natural. Deve ter havido demonstrações de cansaço, bocejos, crianças inquietas, choro de crianças, além do vento frio do início da primavera que incomodava os "atores em cena". No entanto, as imagens selecionadas não registram valores disfóricos, ao contrário, todas investem na euforização da cerimônia.

${ }^{6}$ A "falta" proppiana, do nível narrativo, evoluiu para a "imperfeição" (Greimas, 2002) que conceitua o descompasso entre aquilo que se apreende e aquilo que se visa, descompasso que resulta numa tomada de consciência da incompletude para o sujeito. A aspectualização, desenvolvida por Greimas e aprofundada pela semiótica tensiva, pretende dar conta desses estratos mais profundos pela inserção do gradual sobre o contínuo, que estamos desenvolvendo nessa análise.

${ }^{7}$ Zilberberg (2002a: 21; 2002b: 139 ) evidencia a "latência discursiva da concessão", daí a fascinação da práxis pela dimensão concessiva que, nesse texto, funciona da seguinte forma: a morte inevitável, o fim de tudo é inúmeras vezes repetido. Como invalidar esse fim? Pela
} 
possibilidade de santificação, uma operação tensiva de ordem retórica, a concessão: embora seja humano, deverá ser santificado.

${ }^{8}$ Hjelmslev prevê gradações de dependência entre os termos, propondo a dependência mútua, ou interdependência, passando pela dependência unilateral, pela dependência frouxa, até chegar a termos incompatíveis, que se excluem mutualmente (2003: 29). 


\section{ANEXO 1 \\ Um dia que ficará na história (Texto apresentado no Jornal Nacional de 08/04/2005)}

Fátima Bernardes: $O$ mundo se despediu hoje do Papa que teve o terceiro mais longo pontificado da história. Vamos direto ao Vaticano, ao vivo, onde está William Bonner. Boa noite, William.

William Bonner: Boa noite, Fátima. Boa noite a todos. Esta sexta-feira foi um desses dias em que o jornalismo, certamente, antecipou páginas dos futuros livros de história. A correspondente Ilze Scamparini e o cenografista Mauricio della Constanza acompanharam a cerimônia de adeus a João Paulo II, presidida pelo cardeal alemão Joseph Ratzinger.

(Reportagem)

1. Não é uma manhã de Cracóvia, mas da Roma que ele adotou como sua. Dentro da Praça de São Pedro são 300 mil que esperam ver pela última vez um papa na sua dimensão humana. Um corpo.

2. Os padres saem primeiro, pela porta central da Brasílica, e também pela grande porta sai o Papa. O caixão, carregado por 12 homens que serviram a ele, os patriarcas das igrejas do Oriente e 140 cardeais vestidos de vermelho, cor do luto dos papas.

3. O corpo do Papa João Paulo II chega ao sagrado da Basílica de São Pedro. O povo aplaude emocionado.

4. Emoção e sobressalto. O Papa agora não tem um rosto. Está confinado num caixão de cipreste. O corpo do Papa é posto no chão, não no mármore frio, mas sobre um tapete oriental. E sobre o caixão, o evangelho, aberto.

5. O vento faz tremular a batina dos cardeais e folheia o Livro Sagrado. O vento que a Igreja acredita ter sido enviado pelo Espírito Santo. A missa de corpo presente é rezada em latim. O coro da Capela Sistina e da Mater Eclaesia aumentam a comoção.

6. Uma multidão sem precedentes. Três milhões de pessoas, na Praça de São Pedro, nas ruas próximas e distantes do Vaticano. Um funeral sem precedentes. Com todas as honras, ritos, trajes e cantos. Hoje, oficialmente, Roma e o mundo se despedem do Papa João Paulo II.

7. Para muitos ele foi também um papa sem precedentes. No meio dos fiéis, faixas já o proclamam santo. A homilia do cardeal Joseph Ratzinger é interrompida 13 vezes por aplausos. O decano do colégio de cardeais lembra a infância e a orfandade de Karol Wojtyla.

8. O teatro, a poesia, a vida de operário e a opressão Nazista. Hoje a orfandade é do mundo, que veio à Roma por ele. Chefes de estado e de governo. Reis e rainhas. Foram 9. nações que transmitiram ao vivo os funerais. "João Paulo II está agora na janela da casa do Pai, nos vê e nos abençoa", diz o cardeal Ratzinger, que encomenda o corpo do Pontífice.

10. Quase três horas de exéquias. A multidão se agita, se comove mais uma vez.

11. Hora do adeus ao Papa João Paulo II. Acabou o poder temporal de João Paulo II. Fica a força da sua palavra e das lutas que ele travou. A Praça de São Pedro está em lágrimas. 
12. O caixão é erguido. Os funcionários do Vaticano que o carregam, voltam e o exibem ao povo. O corpo do Papa recebe um aplauso interminável.

13. Os sinos da Basílica encerram a cerimônia. Bispos acenam num gesto de despedida. Agora é a terra nua. O Papa morto é levado para dentro, para os subterrâneos do Vaticano, ao lado de Pedro.

14. O corpo do Papa é posto em mais dois caixões. De zinco e de carvalho. Um dentro do outro. Na Gruta Vaticana, o Papa é sepultado no túmulo que pertenceu a João XXIII, ao lado de duas rainhas que viraram santas, e perto de Pedro.

15. Um punhado de terra polonesa é posto na sepultura. E uma simples lápide. Na crença dos pontífices romanos, quando um papa morre, passa a ser homem. João Paulo II certa vez confidenciou: "Eu não morrerei completamente". 
ANEXO 2

Imagens captadas do Jornal Nacional apresentado em 08/04/2005

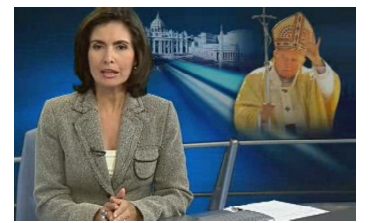

Fig. 1

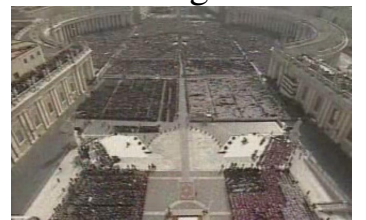

Fig. 4

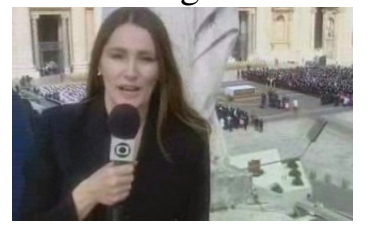

Fig. 7

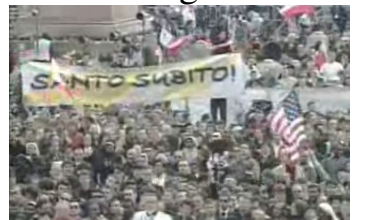

Fig. 10

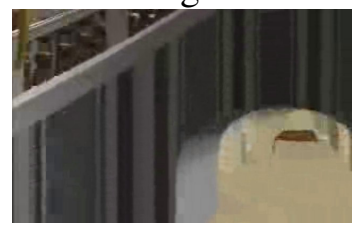

Fig. 13

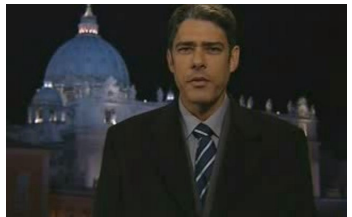

Fig. 2

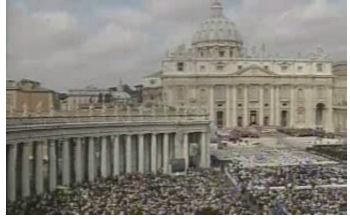

Fig. 5

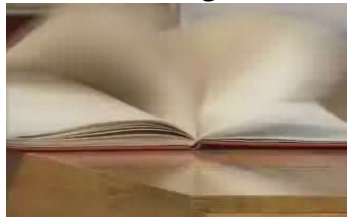

Fig. 8

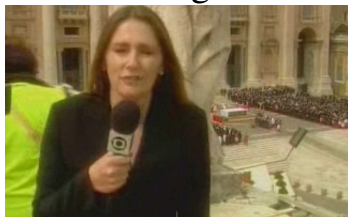

Fig. 11

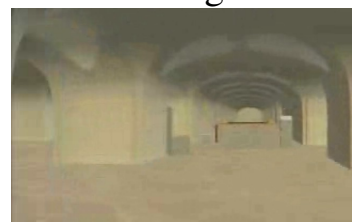

Fig. 14

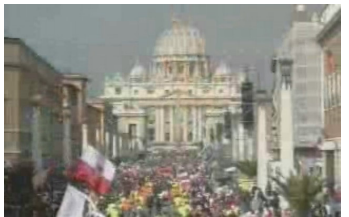

Fig. 3

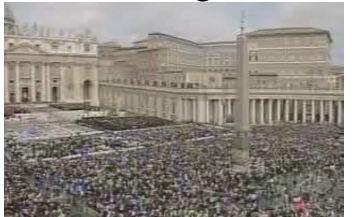

Fig. 6

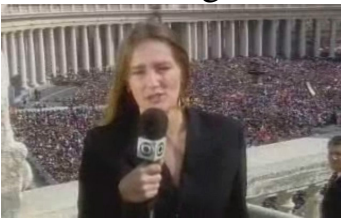

Fig. 9

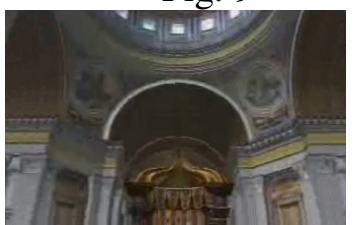

Fig. 12

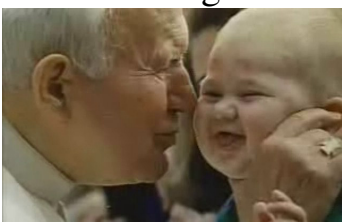

Fig. 15

\section{Como citar este artigo:}

DINIZ, Maria Lúcia Vissotto Paiva. Práxis enunciativa no telejornal: tensividade em notícia. Estudos Semióticos, Número 2, São Paulo, 2006. Disponível em <www.fflch.usp.br/dl/semiotica/es>. Acesso em "dia/mês/ano". 